\title{
Effects of variation in the number and developmental stage of donor embryos and ovulation status of the surrogate mother on the efficiency of pig somatic cell cloning
}

\author{
Mi-Ryung Park ${ }^{1, \#}$, Jae Gyu Yoo ${ }^{1, \#, ~ C h a n g-G i ~ H u r ², ~ B o-W o o n g ~ S i m ~}{ }^{3}$, Myunghoo Kim ${ }^{4}$, \\ Jakyeom Seo ${ }^{4}$, Byeong-Woo Kim ${ }^{4}$, Byung-Wook Cho ${ }^{4}$, Teak-Soon Shin ${ }^{4}$ and Seong-Keun Cho ${ }^{4, *}$ \\ ${ }^{1}$ National Institute of Animal Science, Rural Department of Agriculture, Wanju 55365, Korea \\ ${ }^{2}$ CRONEX, Inc., Hwaseong 18525, Korea \\ ${ }^{3}$ National Primate Research Center \& Futuristic Animal Resource \& Research Center, Korea Research Institute of \\ Bioscience and Biotechnology, Ochang 28116, Korea \\ ${ }^{4}$ Department of Animal Science, College of Natural Science and Life Science, Life and Industry Convergence Research \\ Institute (RICRI), Pusan National University, Miryang 50463, Korea
}

Received August 27, 2020

Revised September 16, 2020

Accepted September 18, 2020

\section{*Correspondence}

Seong-Keun Cho

E-mail: skcho@pusan.ac.kr

ORCID

https://orcid.org/0000-0001-9309-2327

"These authors contributed equally to this work.
ABSTRACT This study investigated the effect of variation in the number of somaticcell-cloned embryos and their developmental stage at transfer on pregnancy, as well as the influence of the estrus status of recipient pigs on in vivo development of cloned porcine embryos after embryo transfer. For somatic cell nuclear transfer (SCNT), fibroblast cells were obtained from a male porcine fetus. Recipient oocytes were collected from prepubertal gilts at a local abattoir and then cultured. After SCNT, reconstructed embryos of different numbers and developmental stages were transferred into recipient pigs. The developmental stage of the cloned embryos and the number of transferred embryos per surrogate showed no significant differences in terms of the resulting cloning efficiency. However, the pregnancy rate improved gradually as the number of transferred cloned embryos was increased from 100150 or 151-200 to 201-300 per recipient. In pre-, peri-, and post-ovulation stages, pregnancy rates of $28.6 \%, 41.8 \%$, and $67.6 \%$ and 16,52 , and 74 offspring were recorded, respectively. The number of cloned embryos and estrus status of the recipient pig at the time of transfer of the cloned embryo affect the efficiency of pig production; therefore, these variables should be particularly considered in order to increase the efficiency of somatic cell pig cloning.

Keywords: cloned embryo, embryo transfer, ovary, pig, recipient

\section{INTRODUCTION}

The technology of somatic cell nuclear transfer (SCNT) in mammals has progressed over the past few decades since the production of the first cloned sheep from a mammary gland cell (Wilmut et al., 1997). This technology has been applied in many fields, such as the genetic improvement of farm animals, the rescue of endangered 
species, and the production of transgenic animals for therapeutic applications. Pig SCNT has also been studied with the aim of improving the efficiency of production (Betthauser et al., 2000; Huang et al., 2000; Onishi et al., 2000; Polejaeva et al., 2000; Li et al., 2013; Rim et al., 2013; Callesen et al., 2014; Huan et al., 2015; Yoo et al., 2017; Jeong et al., 2020).

Given the low efficiency of SCNT, many questions on the mechanisms involved remain unanswered in both basic and applied fields. The difficulty in porcine cloning has been attributed to multiple factors, including oocyte quality (in vivo matured vs. in vitro matured), donor cell type, inadequacies in the culture and media used during the micromanipulation process, lack of an efficient activation method, requirement for a minimum number of fetuses, and the appropriate recipient conditions to maintain a pregnancy (Bang et al., 2002; Yoo et al., 2017; Dang-Nguyen et al., 2020). Polejaeva et al. (2000) reported the first successful birth of five healthy cloned female piglets by SCNT using in vivo-matured oocytes. Around the same time, Onishi et al. (2000) reported the birth of a single, cloned female piglet from in vivo-matured oocytes using piezo-actuated microinjection. These studies used the difficult SCNT procedure and expensive in vivomatured oocytes for the production of cloned piglets. In contrast, Betthauser et al. (2000) systematically optimized each step of SCNT procedure, including sourcing oocytes and in vitro oocyte maturation, culture of donor cells, activation of oocytes following fusion, in vitro culture of embryos, and transfer of embryos to recipient gilts. This led to a more reproducible methodology; however, the efficiency of production of normal, live, cloned offspring remained very low.

Different approaches to the improvement of pig SCNT efficiency have indicated that selection of a suitable donor cell type, ovulation status in recipient gilts, and transfer of an appropriate number of cloned embryos could increase the success rate of piglet cloning (Koo et al., 2010; Li et al., 2013; Rim et al., 2013; Wei et al., 2013; Huan et al., 2015; Shi et al., 2015).

Although most of these factors are important, optimization of the embryo transfer conditions is one of the key steps for producing cloned piglets. Studies have suggested factors affect the pregnancy rate of pig SCNT, such as ovulation status of surrogated gilts, and the number and duration of in vitro cloned embryos for transfer (Petersen et al., 2008; Koo et al., 2010; Schmidt et al., 2010; Huang et al., 2013; Li et al., 2013; Rim et al., 2013; Liu et al., 2014). However, these previous studies were usually performed using an inaccurate synchronization program or a relatively small number of surrogate mothers. Therefore, the present study was conducted to investigate the effect of the following three factors on cloning efficiency using a more accurate synchronization program and a large number of surrogate mothers: the estrus status of the surrogate mother, cleavage stage, and the number of cloned embryos for transfer.

\section{MATERIALS AND METHODS}

\section{Isolation and in vitro culture of porcine somatic cells}

Fibroblast cells were obtained from a male porcine fetus. The cells were cultured in Dulbecco's Modified Eagle's Medium supplemented with $10 \%$ fetal bovine serum under $5 \% \mathrm{CO}_{2}$ at $37^{\circ} \mathrm{C}$. When fetal fibroblast cells were confluent, the cells were passaged. Donor cells were used for nuclear transfer between passages 4 and 8 of in vitro culture. The cells were used for nuclear transfer within three days of reaching confluence.

\section{In vitro maturation of oocytes}

Ovaries were obtained from prepubertal gilts at a local slaughterhouse and transported to the laboratory at 25$35^{\circ} \mathrm{C}$. Antral follicles $(2-6 \mathrm{~mm}$ in diameter) were aspirated with an 18-gauge needle. Aspirated oocytes, which had an evenly granulated cytoplasm and were surrounded by at least three uniform layers of compact cumulus cells, were selected for in vitro maturation. Approximately 100 oocytes were cultured for $40 \mathrm{~h}$ in four-well plates (Nunc, Roskilde, Denmark), each well of which contained $500 \mu \mathrm{L}$ of TCM-199 (Invitrogen Carlsbad, CA, USA) medium, supplemented with $10 \%$ porcine follicular fluid, $0.6 \mathrm{mmol} / \mathrm{L}$ cysteine, $4 \mathrm{IU} / \mathrm{mL} \mathrm{FSH,} \mathrm{LH,} \mathrm{and} 10 \mathrm{ng} / \mathrm{mL}$ EGF.

\section{Somatic cell nuclear transfer (SCNT)}

Nuclear transfer was carried out as described previously (Park et al., 2004). In brief, matured oocytes with the first polar body were treated in PZM-3 medium supplemented with $0.4 \mathrm{mg} / \mathrm{mL}$ demecolcine (Sigma) and $0.05 \mathrm{~mol} / \mathrm{L} \mathrm{su}-$ crose for $1 \mathrm{~h}$. The treated oocytes were transferred to a medium supplemented with $5 \mathrm{ug} / \mathrm{mL}$ cytochalasin B and $0.4 \mathrm{mg} / \mathrm{mL}$ demecolcine, and the protrusion was removed 
with a beveled pipette. A single donor cell was injected into the perivitelline space of each oocyte and was electrically fused by using two direct current pulses of $150 \mathrm{~V} /$ $\mathrm{mm}$ for $50 \mu \mathrm{sec}$ in $0.3 \mathrm{M}$ mannitol, supplemented with 0.1 $\mathrm{mM} \mathrm{MgSO}$ and $0.01 \%$ PVA and incubated at $39^{\circ} \mathrm{C}$ in $5 \%$ $\mathrm{CO}_{2}$.

After $1 \mathrm{~h}$, the fused oocytes with donor cells that were judged under an inverted microspope were activated by two direct current pulses of $100 \mathrm{~V} / \mathrm{mm}$ for $20 \mu \mathrm{sec}$ in 0.3 $\mathrm{M}$ mannitol supplemented with $0.1 \mathrm{mM} \mathrm{MgSO}_{4}$ and 0.05 $\mathrm{mM} \mathrm{CaCl}$ (Park et al., 2004). Activated embryos were transferred to $\mathrm{PZM}-3$ medium at $39^{\circ} \mathrm{C}$ in $5 \% \mathrm{CO}_{2}$.

\section{Estrus synchronization and embryo transfer}

Eight-month-old gilts were used as the recipients for embryo transfer. Estrus synchronization of the recipient was established as described in previously studies (Onishi et al., 2000; Yoo et al., 2017). Briefly, an i.m. injection of 0.2 mg cloprostenol, a prostaglandin F2 alpha analogue (Planate; Sumitomo Seiyaku, Osaka, Japan), was administered to pregnant gilts ( 8 mo old, 120 to $130 \mathrm{~kg}$ ) on days 33 to 53 of gestation, followed by a second injection of 0.2 mg cloprostenol $24 \mathrm{~h}$ later. One thousand international units of eCG (PMS 1000; Tani, NZ) was administrated i.m. at the same time as the second cloprostenol injection. Ovulation was induced by i.m. injection of 500 IU hCG (Puberogen; Sankyo, Tokyo, Japan) at $72 \mathrm{~h}$ after the eCG injection. At 41 to $42 \mathrm{~h}$ after the hCG injection, 1-4 cell SCNT embryos were then surgically transferred into the oviducts using a straw. The status of the recipient's estrus was divided into the following three groups based on the recipient's ovarian status: pre-ovulation stage group (Graafian follicles), peri-ovulation stage group (Graafian follicles and are bloody), and post-ovulation stage group (corpus hemorrhagicum). Ultrasound was used to test for pregnancy between days 25 and 30 after embryo transfer.

\section{Experimental design}

In Experiment 1, we transferred different numbers of reconstructed embryos into recipient pigs and compared the effect of embryo numbers on pregnancy. In Experiment 2, different developmental stages of reconstructed embryos were transferred into recipient pigs and the effect of the various embryo stages of pregnancy was determined. In the third experiment, we investigated the impact of the estrus status of the recipient pigs on pregnancy after reconstructed embryo transfer.

\section{Statistical analysis}

The data were subjected to arcsine transformation for each replication. The transformed values were analyzed using one-way ANOVA. A value of $p<0.05$ was used to determine statistical significance.

\section{RESULTS}

\section{Experiment 1: Effects of transferred somatic-cell- cloned embryo number on pregnancy}

The effects of the number of somatic-cell-cloned embryos on in vivo development to term were evaluated. After nuclear transfer, embryos were cultured under in vitro conditions and embryos that developed to the one- to four-cell stage were transferred randomly to recipient pigs in three groups with different numbers of transferred embryos (Group 1: 100-150 embryos, Group 2: 151-200 embryos, and Group 3: 201-300 embryos). As shown in Table 1, Group $1(10.0 \%)$ had a significantly lower pregnancy rate than Group 2 (37.9\%) and Group 3 (29.2\%). The farrowing rates were $6.7 \%$ in Group 1, 20.7\% in Group 2, and $25 \%$ in Group 3, but these were not significantly different. In addition, the rate of cloned piglet production did not differ among the three groups.

Table 1. Effect of the number of cloned embryos transferred on pig cloning efficiency

\begin{tabular}{|c|c|c|c|c|c|}
\hline $\begin{array}{l}\text { Range of the number of } \\
\text { embryos transferred }\end{array}$ & $\begin{array}{l}\text { No. of } \\
\text { recipients used }\end{array}$ & $\begin{array}{l}\text { No. of embryos transferred } \\
\text { (Mean No./recipient) }\end{array}$ & $\begin{array}{c}\text { No. of recipients } \\
\text { pregnant }(\%)\end{array}$ & $\begin{array}{l}\text { No. of recipients } \\
\text { farrowed (\%) }\end{array}$ & $\begin{array}{c}\text { No. of cloned } \\
\text { piglets born (\%) }\end{array}$ \\
\hline $100-150$ & 30 & $3,537(117.9)$ & $3(10.0)^{b}$ & $2(6.7)$ & $8(0.22)$ \\
\hline $201-300$ & 24 & $5,895(245.6)$ & $7(29.2)^{a}$ & $6(25.0)$ & $25(0.42)$ \\
\hline
\end{tabular}

$\overline{a, b}$ Values in the same column with different superscripts differ significantly $(p<0.05)$. 


\section{Experiment 2: Effect of embryo development stage} for embryo transfer on the efficiency of pig cloning

To examine the effects of the developmental stage of somatic-cell-cloned embryos on cloned pig production at the time of embryo transfer to recipient pigs, the reconstructed embryos were cultured for 12-24 h and 150-300 embryos were transferred into recipient pigs in four different groups (Group A: one-cell-stage embryos, Group B: one- to two-cell-stage embryos, Group C: two- to fourcell-stage embryos, and Group D: one- to four-cell-stage embryos). As shown in Table 2, the pregnancy rates were $23.8 \%$ in Group A, $22.2 \%$ in Group B, $15.4 \%$ in Group C, and $30 \%$ in Group D. The farrowing rates were $14.3 \%$ in Group A, 22.2\% in Group B, 11.5\% in Group C, and 20\% in Group D. These two variables did not show significant differences among the groups. In addition, the rate of production of cloned piglets did not differ among the four groups.

\section{Experiment 3: Effect of ovulation status of surrogate gilts on pig cloning efficiency}

To determine the effect of estrus status of recipient gilts on the successful generation of somatic cell nuclear transfer (SCNT) pigs, one- to four-cell-stage embryos were transferred into the oviducts of recipient gilts with three different ovarian statuses in Table 3 (Type A: Pre-ovulation, Type B: Peri-ovulation, Type C: Post-ovulation; Fig. 1). Type C showed significantly higher pregnancy and farrow rates than the other types. However, there was no significant difference in the mean numbers of cloned piglets per recipient among the three types.

Table 2. Effect of embryo stages on pig cloning efficiency

\begin{tabular}{lccccc}
\hline $\begin{array}{c}\text { Group } \\
\text { (embryo stage) }\end{array}$ & $\begin{array}{c}\text { No. of } \\
\text { recipients used }\end{array}$ & $\begin{array}{c}\text { No. of embryos transferred } \\
\text { (Mean No./recipient) }\end{array}$ & $\begin{array}{c}\text { No. of recipients } \\
\text { pregnant (\%) }\end{array}$ & $\begin{array}{c}\text { No. of recipients } \\
\text { farrowed (\%) }\end{array}$ & $\begin{array}{c}\text { No. of cloned } \\
\text { piglets born (\%) }\end{array}$ \\
\hline Group A (1 cell) & 21 & $3,202(152.5)$ & $5(23.8)$ & $3(14.3)$ & $12(0.38)$ \\
Group B (1-2 cell) & 9 & $2,401(266.8)$ & $2(22.2)$ & $2(22.2)$ & $6(0.25)$ \\
Group C (2-4 cell) & 26 & $4,411(169.7)$ & $4(15.4)$ & $3(11.5)$ & $10(3.3)$ \\
Group D (1-4 cell) & 10 & $1,521(152.1)$ & $3(30.0)$ & $2(20.0)$ & $9(4.5)$ \\
\hline
\end{tabular}

Table 3. Effect of ovulation status of surrogate gilts on pig cloning efficiency

\begin{tabular}{cccccc}
\hline $\begin{array}{c}\text { Recipient } \\
\text { condition* }^{*}\end{array}$ & $\begin{array}{c}\text { No. of } \\
\text { recipients used }\end{array}$ & $\begin{array}{c}\text { No. of embryos transferred } \\
\text { (Mean No./recipient) }\end{array}$ & $\begin{array}{c}\text { No. of recipients } \\
\text { pregnant (\%) }\end{array}$ & $\begin{array}{c}\text { No. of recipients } \\
\text { farrowed (\%) }\end{array}$ & $\begin{array}{c}\text { No. of cloned piglets born } \\
\text { (Mean } \pm \text { SD/recipient) }\end{array}$ \\
\hline Type A & 21 & $7,528(358.4)$ & $6(28.6)^{b}$ & $4(19.0)^{b}$ & $16(4.00 \pm 2.45)$ \\
Type B & 55 & $18,737(340.7)$ & $23(41.8)^{b}$ & $16(29.1)^{b}$ & $52(3.25 \pm 1.95)$ \\
Type C & 37 & $12,944(349.8)$ & $25(67.6)^{\mathrm{b}}$ & $20(54.1)^{\mathrm{a}}$ & $74(3.70 \pm 2.15)$ \\
\hline
\end{tabular}

*A: Pre-ovulation, B: Peri-ovulation, C: Post-ovulation.

a,b Values in the same column with different superscripts differ significantly $(p<0.05)$.
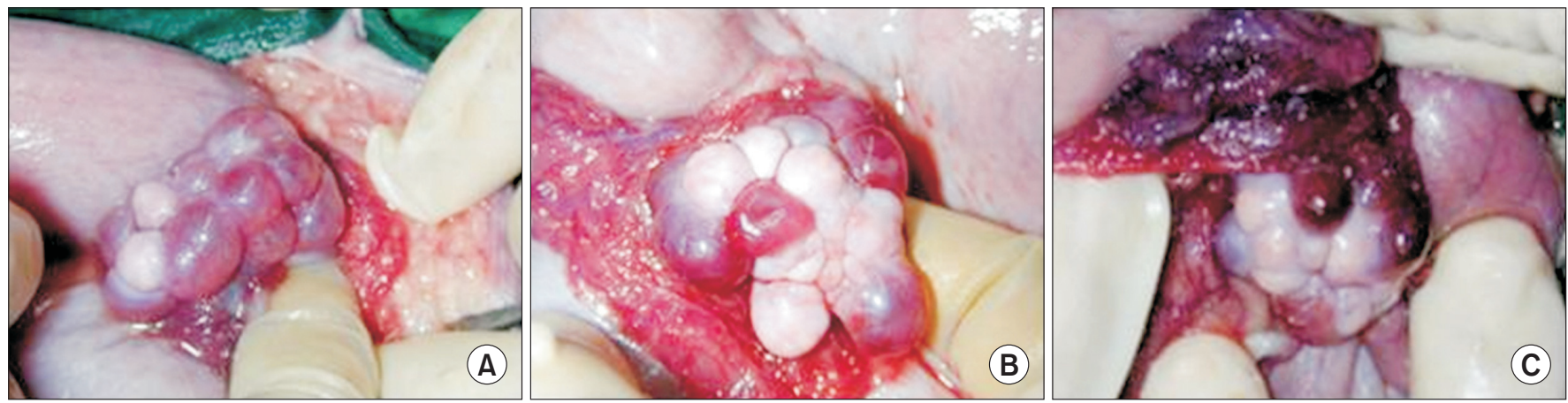

Fig. 1. Recipient ovulation status before the transfer of cloned embryos. (A) Pre-ovulation, follicles large and developed. (B) Periovulation, follicles partly ovulated. (C) Post-ovulation, follicles all ovulated. 


\section{DISCUSSION}

Because somatic cell animal cloning is very complicated, many factors affect its efficiency. In this study, the effects of major factors, including the number and developmental stage of cloned embryos for embryo transfer, and the ovulation status of recipient gilts on the overall cloning efficiency were examined, in order to improve the generation of cloned pigs.

In pigs, signals from three or more embryos are required to maintain pregnancy (King et al., 2002). The pregnancy and delivery rates of surrogate females receiving SCNT embryos are usually lower than those resulting from the transfer of fertilized embryos (Hornen et al., 2007; $\mathrm{Ku}-$ rome et al., 2008; Salilew-Wondim et al., 2013). One possible reason for this is that the low developmental ability of cloned embryos significantly reduces their signaling to the recipient mother after embryo transfer. Therefore, they are unable to cause the establishment of pregnancy in the recipients or help in maintaining pregnancy to term. If this is correct, it may be possible to minimize this adverse effect by increasing the number of cloned embryos transferred to an individual surrogate. However, in our study, the transfer of more than 100 cloned embryos did not appear to markedly influence the pregnancy and delivery rates of the recipients.

It has been shown that in vitro culture cannot provide porcine embryos with a developmental environment that is comparable to in vivo conditions (Macháty et al., 1998; Nakamura et al., 2017). In many pig SCNT studies, short in vitro culture times for cloned embryos before embryo transfer were used instead of longer ones (Liu et al., 2014; Shi et al., 2015). Our study used SCNT embryos cultured both for a shorter time (one-cell-stage embryos for $16 \mathrm{~h}$ ) and for a longer time (one-cell, one- to two-cell, two- to four-cell, and one- to four-cell embryos for 16-40 h) and found that culture time prior to transfer did not significantly affect the rates of pregnancy and delivery.

The estrus status of recipient gilts has been considered important for the outcome of SCNT in pig (Koo et al., 2010; Huang et al., 2013; Huan et al., 2015). It is known that synchronization between cloned embryos and surrogates determines the subsequent development of pregnancy, and that the primary cause of failure in the development of cloned embryos, transferred 14-h postactivation into surrogates with different estrus stages, is related to the coordination of synchronization. The results of the present study show that surrogates on Day 2 of estrus were more suitable for the implantation and full-term development of cloned embryos. One possible explanation for this is that the cloned embryos develop at a slower rate than their in vivo counterparts and are synchronized with the surrogates on Day 2 of estrus when cultured 14-h post-activation (Martin et al., 2007). In the present study, nearly all of the surrogates in the postovulation group carried the cloned embryos to full term and gave birth to cloned piglets.

In conclusion, we have successfully cloned pigs under conditions of varying embryo numbers and developmental stages, and different estrus statuses of recipient gilts. It is acknowledged that animal cloning is a complicated process, and many other potential factors such as embryo quality should be investigated. Our results should help improve pigs SCNT and other important animals and should provide insights into the factors that affect cloning in animals.

\section{CONFLICTS OF INTEREST}

No potential conflict of interest relevant to this article was reported.

\section{ACKNOWLEDGEMENTS}

This work was supported by a 2-Year Research Grant of Pusan National University.

\section{AUTHOR CONTRIBUTIONS}

Conceptualization: Mi-Ryung Park, Jae Gyu Yoo and Seong-Keun Cho

Data curation: Mi-Ryung Park and Jae Gyu Yoo

Formal analysis: Mi-Ryung Park, Jae Gyu Yoo, Byeong-

Woo Kim, Jakyeom Seo, Myunghoo Kim, Byung-Wook Cho and Teak-Soon Shin

Funding acquisition: Seong-Keun Cho

Investigation: Mi-Ryung Park and Jae Gyu Yoo

Methodology: Mi-Ryung Park and Jae Gyu Yoo

Project administration: Mi-Ryung Park, Jae Gyu Yoo and Seong-Keun Cho

Resources: Chang-Gi Hur, Mi-Ryung Park and SeongKeun Cho 


\section{Supervision: Seong-Keun Cho}

Validation: Mi-Ryung Park and Jae Gyu Yoo

Writing - original draft: Mi-Ryung Park and Jae Gyu Yoo

Writing - review \& editing: Jae Gyu Yoo, Bo-Woong Sim and Seong-Keun Cho

\section{AUTHOR'S POSITION AND ORCID NO.}

\author{
MR Park, PhD, \\ https://orcid.org/0000-0001-5452-5281 \\ JG Yoo, PhD, \\ https://orcid.org/0000-0002-8542-9193 \\ CG Hur, PhD, \\ https://orcid.org/0000-0003-4526-3886 \\ BW Sim, PhD, \\ https://orcid.org/0000-0002-4492-1085 \\ M Kim, Professor, \\ https://orcid.org/0000-0002-8444-6952 \\ J Seo, Professor, \\ https://orcid.org/0000-0002-9176-5206 \\ BW Kim, Professor, \\ https://orcid.org/0000-0003-3300-0173 \\ BW Cho, Professor, \\ https://orcid.org/0000-0002-7739-1391 \\ TS Shin, Professor, \\ https://orcid.org/0000-0001-5362-9206 \\ SK Cho, Professor, \\ https://orcid.org/0000-0001-9309-2327
}

\section{REFERENCES}

Bang JI, Yoo JG, Park MR, Shin TS, Cho BW, Lee HG, Kim BW, Kang TY, Kong IK, Kim JH, Cho SK. 2013. The effects of artificial activation timing on the development of SCNT-derived embryos and newborn piglets. Reprod. Biol. 13:127-132.

Betthauser J, Forsberg E, Augenstein M, Childs L, Eilertsen K, Enos J, Forsythe T, Golueke P, Jurgella G, Koppang R, Lesmeister T, Mallon K, Mell G, Misica P, Pace M, PfisterGenskow M, Strelchenko N, Voelker G, Watt S, Thompson S, Bishop M. 2000. Production of cloned pigs from in vitro systems. Nat. Biotechnol. 18:1055-1059.

Callesen H, Liu Y, Pedersen HS, Li R, Schmidt M. 2014. Increasing efficiency in production of cloned piglets. Cell. Reprogram. 16:407-410.

Dang-Nguyen TQ, Wells D, Haraguchi S, Men NT, Nguyen HT, Noguchi J, Kaneko H, Kikuchi K. 2020. Combined refinements to somatic cell nuclear transfer methods improve porcine embryo development. J. Reprod. Dev. 66:281-286.

Hornen N, Kues WA, Carnwath JW, Lucas-Hahn A, Petersen B,
Hassel P, Niemann H. 2007. Production of viable pigs from fetal somatic stem cells. Cloning Stem Cells 9:364-373.

Huan Y, Hu K, Xie B, Shi Y, Wang F, Zhou Y, Liu S, Huang B, Zhu J, Liu Z, He Y, Li J, Kong Q, Liu Z. 2015. Ovulation statuses of surrogate gilts are associated with the efficiency of excellent pig cloning. PLoS One 10:e142549.

Huang Y, Ouyang H, Yu H, Lai L, Pang D, Li Z. 2013. Efficiency of porcine somatic cell nuclear transfer - a retrospective study of factors related to embryo recipient and embryos transferred. Biol. Open 2:1223-1228.

Jeong PS, Sim BW, Park SH, Kim MJ, Kang HG, Nanjidsuren T, Lee S, Song BS, Koo DB, Kim SU. 2020. Chaetocin improves pig cloning efficiency by enhancing epigenetic reprogramming and autophagic activity. Int. J. Mol. Sci. 21:4836.

King TJ, Dobrinsky JR, Zhu J, Finlayson HA, Bosma W, Harkness L, Ritchie WA, Travers A, McCorquodale C, Day BN, Dinnyés A, De Sousa PA, Wilmut I. 2002. Embryo development and establishment of pregnancy after embryo transfer in pigs: coping with limitations in the availability of viable embryos. Reproduction 123:507-515.

Koo OJ, Kang JT, Kwon DK, Park HJ, Lee BC. 2010. Influence of ovulation status, seasonality and embryo transfer method on development of cloned porcine embryos. Reprod. Domest. Anim. 45:773-778.

Kurome M, Ishikawa T, Tomii R, Ueno S, Shimada A, Yazawa H, Nagashima H. 2008. Production of transgenic and nontransgenic clones in miniature pigs by somatic cell nuclear transfer. J. Reprod. Dev. 54:156-163.

Li Z, Shi J, Liu D, Zhou R, Zeng H, Zhou X, Mai R, Zeng S, Luo L, Yu W, Zhang S, Wu Z. 2013. Effects of donor fibroblast cell type and transferred cloned embryo number on the efficiency of pig cloning. Cell. Reprogram. 15:35-42.

Liu Y, Li J, Løvendahl P, Schmidt M, Larsen K, Callesen H. 2015. In vitro manipulation techniques of porcine embryos: a meta-analysis related to transfers, pregnancies and piglets. Reprod. Fertil. Dev. 27:429-439.

Macháty Z, Day BN, Prather RS. 1998. Development of early porcine embryos in vitro and in vivo. Biol. Reprod. 59:451455.

Martin L, Besch-Williford C, Lai L, Cheong HT, Im GS, Park KW, Murphy C, Hao Y, Ellersieck MR, Keisler DH, Schatten H, Green JA, Prather RS. 2007. Morphologic and histologic comparisons between in vivo and nuclear transfer derived porcine embryos. Mol. Reprod. Dev. 74:952-960.

Nakamura Y, Tajima S, Kikuchi K. 2017. The quality after culture in vitro or in vivo of porcine oocytes matured and fertilized in vitro and their ability to develop to term. Anim. Sci. J. 88:1916-1924.

Onishi A, Iwamoto M, Akita T, Mikawa S, Takeda K, Awata T, Hanada H, Perry AC. 2000. Pig cloning by microinjection of fetal fibroblast nuclei. Science 289:1188-1190.

Park MR, Cho SK, Park JY, Lee SY, Choi YJ, Kwon DN, Son WJ, Seo HG, Kim JH. 2004. Detection of rare Leydig cell hypoplasia in somatic cell cloned male piglets. Zygote 12:305-313.

Petersen B, Lucas-Hahn A, Oropeza M, Hornen N, Lemme E, 
Hassel P, Queisser AL, Niemann H. 2008. Development and validation of a highly efficient protocol of porcine somatic cloning using preovulatory embryo transfer in peripubertal gilts. Cloning Stem Cells 10:355-362.

Polejaeva IA, Chen SH, Vaught TD, Page RL, Mullins J, Ball S, Dai Y, Boone J, Walker S, Ayares DL, Colman A, Campbell KH. 2000. Cloned pigs produced by nuclear transfer from adult somatic cells. Nature 407:86-90.

Rim CH, Fu Z, Bao L, Chen H, Zhang D, Luo Q, Ri HC, Huang H, Luan Z, Zhang Y, Cui C, Xiao L, Jong UM. 2013. The effect of the number of transferred embryos, the interval between nuclear transfer and embryo transfer, and the transfer pattern on pig cloning efficiency. Anim. Reprod. Sci. 143:91-96.

Salilew-Wondim D, Tesfaye D, Hossain M, Held E, Rings F, Tholen E, Looft C, Cinar U, Schellander K, Hoelker M. 2013. Aberrant placenta gene expression pattern in bovine pregnancies established after transfer of cloned or in vitro produced embryos. Physiol. Genomics 45:28-46.

Schmidt M, Kragh PM, Li J, Du Y, Lin L, Liu Y, Bøgh IB, Winther KD, Vajta G, Callesen H. 2010. Pregnancies and piglets from large white sow recipients after two transfer methods of cloned and transgenic embryos of different pig breeds. Theriogenology 74:1233-1240.

Shi J, Zhou R, Luo L, Mai R, Zeng H, He X, Liu D, Zeng F, Cai G, Ji H, Tang F, Wang Q, Wu Z, Li Z. 2015. Influence of embryo handling and transfer method on pig cloning efficiency. Anim. Reprod. Sci. 154:121-127.

Wei H, Qing Y, Pan W, Zhao H, Li H, Cheng W, Zhao L, Xu C, Li H, Li S, Ye L, Wei T, Li X, Fu G, Li W, Xin J, Zeng Y. 2013. Comparison of the efficiency of Banna miniature inbred pig somatic cell nuclear transfer among different donor cells. PLoS One 8:e57728.

Wilmut I, Schnieke AE, McWhir J, Kind AJ, Campbell KH. 1997. Viable offspring derived from fetal and adult mammalian cells. Nature 385:810-813.

Yoo JG, Kim BW, Park MR, Kwon DN, Choi YJ, Shin TS, Cho BW, Seo J, Kim JH, Cho SK. 2017. Influences of somatic donor cell sex on in vitro and in vivo embryo development following somatic cell nuclear transfer in pigs. Asian-Australas. J. Anim. Sci. 30:585-592. 